\title{
Járt utat a járatlanért...
}

\section{Könyvismertetés Halmai Péter (szerk.) A brexit forgatókönyvei és hatásai című tanulmánykötetéről}

Soha aktuálisabb időpontot $A$ brexit forgatókönyvei és hatásai tanulmánykötet összegzéséhez. Az Európai Unió és Egyesült Királyság közötti kereskedelmi és együttmúködési megállapodáson alig száradt meg a tinta, a lehetetlennek tűnő megegyezés feletti pillanatnyi eufóriát egyetlen nap alatt felváltották az európai repterekről visszafordított brit utasokról, tanácstalan fuvarozókról és Skócia megerősített függetlenségi céljairól szóló hírek. Nehéz a brexit népszavazás okainak és várható következményeinek összetettségét és ellentmondásosságát érzékeltetni. A tanulmánykötet - amely A modern állam gazdasági szerepének legújabb dimenziói elnevezésű Ludovika Kiemelt Kutatómúhely kutatásai keretében készült - hiánypótló jelleggel a legfontosabb politikai, társadalmi, jogi és gazdasági aspektusokat foglalja össze. ${ }^{1}$

A népszavazást körüllengő kaotikusság folytatódott az Európai Unióval folytatott tárgyalások és ezzel összefüggő brit belpolitikai folyamatok irányításában és szervezésében is, a brit álláspont erős képlékenységét, következésképpen pozíciójának jelentős, folyamatos átalakulását eredményezve. Egészen 2020. december 24-ig fennállt a kézirat lezárásának időpontjában is érzékelhető nagyfokú bizonytalanság az Egyesült Királyság távozásának módját és az Európai Unióval kialakuló jövőbeni viszonyát illetően. A tanulmánykötet relevanciáját illusztrálja, hogy a szerzők által felvetett dilemmák egyrészt végigkísérték a négy és fél éves tárgyalássorozatot, továbbá közülük számos fajsúlyos, rendezésre szoruló követelmény megválaszolatlan maradt a nehezen megszületett megállapodás keretei között is.

A kötetben rendhagyó módon két Előszón is található. Azokból kitűnik a multidiszciplináris tanulmánykötet elkészítésének fő célja, a brexit több tudományterület oldaláról történő megvilágításának, magyarázatának igénye. Ugyanakkor - minthogy a kötet

Kondor Zsuzsanna a Nemzeti Közszolgálati Egyetem Államtudományi és Nemzetközi Tanulmányok Kar Közpénzügyi Tanszék mesteroktatója. E-mail: kondor.zsuzsanna@uni-nke.hu

Az NKE-n folytatott kutatások keretében már rögtön a referendum után multidiszciplináris elemzés készült. Lásd: Bóka János - Halmai Péter - Koller Boglárka: Válás „angolosan”: A BREXIT politikai, jogi és gazdasági agendái. Pro Publico Bono - Magyar Közigazgatás, (2016), 2. 58-79.

Halmai Péter (szerk.): A brexit forgatókönyvei és hatásai. Budapest, Ludovika Egyetemi Kiadó, 2020. 9-10., 11-12. 
közgazdaságtudományi kutatómúhely keretében készült - abban kiemelt helyet foglal el a brexit gazdaságtudományi elemzése. (A terjedelem mintegy háromnegyedét teszi ki.) ${ }^{3}$

Koller Boglárka Új Európa március 29. után - a brexit természetrajza című tanulmánya ${ }^{4}$ a népszavazás történeti-politikai előzményeit és közvetlen következményei tárja fel. A szerző azon premisszát vizsgálja, miszerint az Egyesült Királyság az integrációs folyamatra való rácsatlakozásában, uniós tagságában és kilépésének körülményeiben is jól megragadható különutassága. Kötődése eleve megosztott, ehhez társul meggyőződése, miszerint gazdasági és politikai súlyából adódóan irányítania kell a folyamatokat, és erre történelmi-politikai hagyományai okán jogosultságot is érez. Ezért lett véleményem szerint visszatérő probléma, hogy az Egyesült Királyság kimaradt az európai integráció első évtizedeiből, így az intézményi-politikai keretek, a jogi berendezkedés kialakulását nem tudta befolyásolni. A különutasság az Egyesült Királyságnak tett lényeges engedményekkel (például a Margaret Thatcher által kiharcolt visszatérítés, a Maastrichti szerződés opt-out-opciója alapján) egyértelműen igazolható. Az utolsó nagyobb fordulat, a David Cameron miniszterelnök által kezdeményezett hatásköri felülvizsgálat már a népszavazás közvetlen előzményévé vált.

A tanulmány kidomborítja a brit belpolitika, csakúgy, mint az Európai Unió teljes felkészületlenségét a brexit tekintetében. Theresa May a kilépési szándéknyilatkozatot közel háromnegyed év elteltével küldte el; mozgásterét erősen szúkítette a Konzervatív Párton belüli megosztottság, majd a sikertelen előrehozott választásokat követően saját meggyengült pozíciója. A teljes folyamatot végigkísérte az Egyesült Királyság kiérlelt koncepciójának hiánya, a taktikázás és improvizáció.

A szerző az uniós oldalon hangsúlyozza a fennálló jogbizonytalanságot. A kilépés szabályozása önmagában sokféle értelmezést tett lehetővé - az euroszkeptikusoknak tett engedményként a szerződésbe beemelt elvi lehetőség mögül -, hiányosnak bizonyultak a jogi-intézményi részletszabályok is. Uniós oldalon Juncker elnök precedenst alkotott meg a két szakaszból álló folyamat meghatározásával: a kilépésről való megegyezés előfeltétele a jövőbeni viszony definiálásának. További korlátot szabott még a notifikációtól számított kétéves határidő és a Tanács állásfoglalása, miszerint a négy szabadság elve egyetlen és oszthatatlan tárgyalási csomagot képez, az egységes piachoz történő jövőbeni hozzáférés feltételei között nem lehet válogatni (sem elvek, például személyek szabad mozgása, sem ágazatok szerint), továbbá kilépésig az Egyesült Királyság nem folytathatott kétoldalú egyeztetéseket a tagállamokkal (sem).

$\mathrm{Az}$ azonnali rendezést igénylő, közvetlen következmények közül jelentőségénél fogva ki kell emelni 1. az Egyesült Királyságban megtelepedett uniós polgárok és vállalatok (akárcsak az Egyesült Királyság más tagállamokban letelepedett/tartózkodó állampolgárai) megszerzett jogainak megőrzését, 2. az északír-ír határ jellegének megőrzését (nem folyik határellenőrzés) és 3. az Egyesült Királyság korábban vállalt pénzügyi

\footnotetext{
3 A modern állam gazdasági szerepének legújabb dimenziói Ludovika Kiemelt Kutatóműhely keretében készült integrációelméleti kötet, illetve a szerző legutóbbi átfogó műve is magukban foglalják, illetve még szélesebb összefüggésrendszerbe helyezik a dezintegráció és a brexit problémakörét. Halmai Péter: Európai gazdasági integráció. Budapest, Dialóg Campus, 2020. 68-76.; Halmai Péter: Mélyintegráció. A Gazdasági és Monetáris Unió ökonómiája. Budapest, Akadémiai Kiadó, 2020.

Halmai (szerk.) (2020) i. m. 13-26.
} 
kötelezettségeinek teljesítését. A kilépési feltételekről szóló közös jelentés elfogadásakor, 2017 decemberében a brexit jellege (hard/soft) még nem nyert körvonalat.

A tanulmány értékes záró gondolata, miszerint kilépő állam nem juthat kedvezőbb feltételekkel az uniós vívmányok, kiemelten az egységes belső piaci előnyeihez, mint tagsága idején, mintha a politikai döntéshozók és véleményformálók jó részének figyelmét elkerülte volna.

A brexit okainak feltárása a társadalomtudományok széles spektrumának művelőit is feltáró munkára késztette. Arató Krisztina Érvek és ellenérvek a brexitkampányban - mit mondanak az Európai Unióról? című tanulmánya ${ }^{5}$ a két ellentábor érvrendszerét és a mögötte álló, az Európai Unióval való viszonyra vonatkozó narratívákat elemzi. A szerző felhívja a figyelmet a tényre, miszerint a brexitszavazáson kinyilvánított értékválasztás megértéséhez a szavazók lakhelyével, társadalmi helyzetével - például etnikum, iskolázottság, jövedelmi viszonyok - összefüggő adottságok nem szolgáltak megfelelő támpontként. Elemzéséhez ezért az interpretatív megközelítést választotta, középpontba a döntésben megtestesülő preferenciáikat alakító narratívákat helyezve.

Bemutatja a mítosz általános, társadalmi identitást formáló funkcióját és működését, kiemeli a politikumban való leképeződését. A valamely politikai rendszerrel és közösséggel való azonosulást segítő, dinamikus jellegű, tehát például média, politikai kampányok által változtatható diskurzus könnyen érthető üzeneteivel, sokféle formájú megjelenítésével átszövi a társadalom életét, a világról való véleményformálást észrevétlenül befolyásolva. Fejlődési szakaszai jól elhatárolhatók, a rituálék kialakulásától, az újramesélés eszközeinek alkalmazásán keresztül a mítosz megkérdőjelezhetetlenségének fázisáig. A mítoszok a társadalomban megvonják a „mi és ők” választóvonalat; az ellenmítoszok lényege, hogy e domináns meghatározást megcáfolják, és új magyarázatokat, alternatív diskurzust nyújtsanak saját közösségük számára. A szerző hangsúlyozza, hogy a mítosz a változó környezetben való megújulásának képtelensége az ellenmítosz megerősödését, sőt dominanciáját vonja maga után.

Az elméleti összefoglalás önmagában új, a hitek-hiedelmek-érzelmek súlyának mérlegelésével összefüggő impulzusokat nyújt a politikai döntési preferenciák érvényesüléséhez; az Európai Unióban ismeretes mítoszok és ellenmítoszok bemutatása ezeket a népszavazás kimenetével összefüggésben konkretizálja. Utalva az alapító mítosz meglétét illető vitákra, a szerző amellett érvel, hogy az unió igenis rendelkezik sikeres narratívákkal.

- A béke mítosza az európai integráció gondolatát a II. világháború pusztításáig, a soha többet szándék, a szembenállás helyett együttmüködés megfogalmazásáig, az Európai Szén és Acélközösségben való intézményesítéséig vezeti vissza. A békemítosz ugyan általánosságban jelen van a politikusok megnyilvánulásaiban, az uniós intézmények kultúrájában és tevékenységében, a globális folyamatokkal összhangban azonban hol háttérbe szorul, hol - kiemelten olyan konfliktushelyzetben, mint a pénzügyi válság - hangsúlyosabbá válik.

- A racionalitás mítosza az 1950-60-as években előtérbe kerülő neofunkcionalizmussal kapcsolható össze. Fő elemei az ágazati szakpolitikák technokrata szemléletű megvalósítása, a racionális döntéshozatalt elősegítő közösségi módszer,

Halmai (szerk.) (2020) i. m. 27-52.

Európai Tükör 2021/1. 
ebből adódóan az intézmények múködésének hatékonyságába vetett meggyőződés. A mítosz táplálásában élen jár az Európai Bizottság - és véleményem szerint bizonyos fokig más intézmények is (például Európai Számvevőszék).

- Az európai integráció gazdasági mítoszának elemzésében a szerző aláhúzza, hogy a politikai integráció mellett a gazdásági együttmúködés új alapokra helyezése is az alapítók szeme előtt lebegett, például Franciaország számára elsődleges fontosságú volt a német szénhez való hozzáférés. A szerző elmagyarázza egyrészt a gazdasági együttmúködés és a kibocsátás, társadalmi jólét közötti, másrészt a politikai unió értelemszerúségével való összekapcsolást.

A gazdasági együttmúködés és innentől fogva az európai projekt sikerébe vetett hitet a pénzügyi válság drasztikusan megtépázta.

- A demokrácia hiánya ellenmítosz középpontjában a sajátos, összetett döntéshozatali rendszer, a közvetlen választás nélküli vezetők irányította intézmények megnövekedett súlya, a valós képviselet jellege (az európai parlamenti választások másodlagos jellege, az EP hiányzó jogosítványai) és az európai polgároktól elidegenedett intézményrendszer áll.

- A nemzeti szuverenitás fenyegetése ellenmítosz a tagállam/nemzetállam mozgástérvesztésére összpontosít. Kiemeli a közösen gyakorolt/átruházott szuverenitás erőteljes bővülését, az egyhangú döntés rendjét nagymértékben felváltó minősített többségi döntéshozatalt. Ennek eredményeként a tagállamoknak olyan döntést is végre kell hajtaniuk, olyan jogszabályt is alkalmazniuk kell, amellyel kormányaik nem értettek egyet. Mindkét ellenmítosz hosszú múltra tekint vissza, és az euroszkeptikus pártoknak, valamint a médiának köszönhetően megerősödött az elmúlt évtizedben.

- A cselekvésképtelenség ellenmítosza az összetett és egyensúlyra törekvő intézményi rendszer sajátos működéséből, a döntéshozatali folyamatok és cselekvések lassúságából, a konszenzuskeresésből adódó tehetetlenségből és/vagy felpuhult, eredménytelen megoldásokból adódik; a nehézségek egyértelmű megvilágítást nyertek egyrészt önmagában a felgyorsult világnak, másrészt az elmúlt évtized megsokasodott drámai eseményeinek köszönhetően.

Megállapítható, hogy a brexitkampányban az első két ellenmítosz elemei, kiemelten a szuverenitás elvesztése (például a munkaerőpiac megnyitása, bevándorlás, jogszabálytenger átvétele, vagy lásd később a halászat ügyét) nagyon nagy hangsúlyt kaptak. Ugyancsak központi szerepet játszott az integráció mint az európai gazdasági prosperitás kérdése is (például a nem szavazók számára fontos üzenet volt az uniós költségvetéshez való hozzájárulás hazai jóléti kiadásokra fordítása, a bevándorlás korlátozásával a szociális kiadások visszaszorítása is). Végül, de nem utolsósorban a szerző következtetései között a narratívák igazságtartalmával kapcsolatos problémákra emlékeztetett.

Kaszap Márton $A$ brexit és a brit pártverseny címú munkája ${ }^{6}$ a népszavazáshoz vezető út 0 . kilométerét kívánja meghatározni a brexit és brit pártverseny összefüggéseire összpontosítva. Mint a szerző is hangsúlyozza, a szakirodalom széles értelmezési

Halmai (szerk.) (2020) i. m. 53-68. 
palettát kínál. Mindenesetre a népszavazás kimenetét tágabb folyamat részeként kell értelmezni, így az előzmények tekintetében a tanulmány ráirányítja a figyelmet a 2010. évi választások eredményezte koalíciós kényszerre. Az önálló kormányzás igénye útkeresésre sarkallta a Konzervatív Pártot: a 2012-ben érkezett új, Lynton Crosby vezette kampánycsapat ideológiai váltást, jobbratolódást hozott, gazdasági problémákra és migrációra szándékozott választ adni. A kampányszakértők megjelenítették a sikeres ausztrál kampány elemeit, a megosztó politizálást, a tradicionális szavazóbázis kiszélesítését segítő egyszerû, érthető, erős és értékválasztást provokáló üzeneteket, a UKIP és Munkáspárt kékgalléros szavazói átcsábításának céljával. Az elsődleges témák közé a gazdaság, a problémák megoldásához szükséges vezetői képességek és indirekt módon a bevándorlás került. E berendezkedés meghatározta a UKIP-pal, mint kisebb, egytémájú és versengő párttal szembeni viszonyt is: a lehetőségek közül (elutasítás, alkalmazkodás, kisajátítás) a Konzervatív Párt végül alkalmazkodó taktikát választott, átvette a UKIP képviselte témát, miközben a párt fontosságát bagatellizálta.

Az unióval való kapcsolatrendszer az euroszkepticizmus erős hagyományai mellett is sokáig jelentéktelen témaként viselkedett, a választások hagyományosan a belpolitikai témák köré szerveződtek, azonban a munkaerőpiac a kelet-közép-európai országok számára történő megnyitása és munkavállalóik tömeges megjelenése új helyzetet teremtett. Az arányos választási rendszerből adódóan az alternatív pártok számára az európai parlamenti választások nyújtanak érdemi lehetőségeket üzeneteik megjelenítésére. Az EP-választások „partvonal” jellege azonban huzamosabb ideig elaltatta a két nagy pártot, nem érzékelték a UKIP tényleges fenyegetését - a népszavazás esetében egyszerű többség követelménye mellett sem. Azonban a téma átterjedt az elsőrendű választásokra is, David Cameron miniszterelnök Bloomberg beszédében ügydöntő népszavazást, ezt megelőzően azonban a brit tagság feltételeinek újratárgyalását irányozta elő. Minthogy utóbbira ráadásul a népszavazást közvetlen megelőző időszakban került sor, a népszavazás óhatatlanul az újratárgyalt pozícióról szólt.

A kompetencia-felülvizsgálati tárgyalásokra összességében kedvezőtlen politikai kontextusban került sor, továbbá az eredményt a brit közvélemény egyértelmúen látszatengedményekként érzékelte. Emellett a legtöbb párt és a Konzervatív Párt vezetése is a maradás mellett kampányolt, az ellenvéleménnyel élő szavazók számára a választási alternatívát alapvetően az elitellenes és kilépéspárti UKIP jelenítette meg. Itt feltétlen említést érdemel a pártverseny dinamikájának az elmúlt évtizedekben végbement változása: a két nagy párt közötti hagyományos, választóik számára eligazodást nyújtó ellentétek feloldódtak, álláspontjaik nagy kérdésekben való hasonlósága ellehetetlenítette a megkülönböztethetőséget markáns értékválasztás igénye esetén. A rendkívül magas (72\%-os) részvétel mellett zajló népszavazás regionálisan nagy eltéréseket hozott, az euroszkeptikusok ugrásszerúen tudták növelni korábbi sikereiket.

A brexit népszavazás dominóeffektust indított el a brit belpolitikában: a Konzervatív Párt destabilizálódott, ezt a miniszterelnök-váltások, pártbeli csatározások világosan tükrözték; a Munkáspárton belül is villongásokat, majd Corbyn sajátos megerősödésével járó hatalmi átrendeződést eredményezett; Farage lemondását - és egyetlen konkrét célkitűzésének realizálását követően - a UKIP többé nem talált magára. Összegzésként a szerző aláhúzta az egyértelmű ok-okozati összefüggéseket, a brexitdominó mögött álló, 2010-ig visszavezethető belpolitikai fejlemények sorozatát, a brexitláncot elindító 
legfontosabb eseményként Lynton Crosby 2012. évi színrelépését azonosította. Végül, de nem utolsósorban a tanulmány a láncszerúségből a dinamika folytatására következtet - mint az események igazolták, nagyon helyesen.

Bóka János A brexit jogi útvesztôi címú tanulmánya ${ }^{7}$ a brexitfolyamat jogi aspektusait és ennek részeként a felmerülő szabályozói hiányosságokat, értelmezési problémákat foglalja össze. A kilépésre vonatkozó előírások többféle megközelítést eredményeztek: a jogászok, jogtudósok egy része az eljárásrendi alapokat és részleteket a nemzetközi szerződésekből igyekezett levezetni, a szakma egy másik része a nemzetközi szervezetekre vonatkozó szabályozást tekintette kiindulásként. A harmadik irányt az alkotmányos szerződés felelevenítése képviselte, ennek megalkotói ugyanis a kilépést a nemzetközi jog alapján eleve vélelmezték, ám célszerűnek tartották az uniós jog hatáskörébe helyezni - egyértelműen politikai megfontolásból. A Lisszaboni szerződés változatlan szövegezéssel vette át a rendelkezéseket az EUSz. 50. cikke keretében - a mögöttes megfontolás az volt, hogy az Európai Unió nem szövetségi állam, a szuverenitástól elválaszthatatlan az egyoldalú kilépés, egyúttal minden más kilépési mód kizárva. A jogbizonytalanság azonban fennmaradt egyrészt a bejelentésig tartó szakasz ismérvei, másrészt a kilépési szándék és kilépés közötti időszak intézményi-jogi viszonyai tekintetében.

A kevés tartalmi fogódzók között említhető az indokolási kötelezettség hiánya, a részleges kilépés és a szerződések területi korlátozási lehetőségének hiánya, illetve az az elöírás, miszerint a kilépésről az alkotmányos követelményekkel összhangban, a feljogosított intézménynek a lefektetett eljárás szerint kell határozatot hoznia. Az Egyesült Királyság Legfelsőbb Bíróságának állásfoglalása a döntést - mégpedig a devolúciós kérdésekre tekintettel osztatlan jelleggel - a Parlament hatáskörébe utalta. Érdemes megjegyezni, hogy az államfő által jóváhagyott törvény nem korlátozta - gyámság alá helyezéssel, következésképpen előzetes parlamenti hozzájárulás követelményével - a brit kormányt a tárgyalás és szerződés aláírása tekintetében. A kilépési szándékot a tagállamnak kifejezetten és célzatosan kellett kinyilvánítania, utóbbi kapcsán a szerző emlékeztet az Egyesült Királyság kifogásolható késlekedésére, amely - a fokozódó politikai feszültségen túl - az EUSZ 4. cikkének (3) bekezdésében lefektetett lojális együttműködés elvének megsértését is felvethette (különös tekintettel uniós tagállamként ugyanezen időszakban más államokkal folytatott tárgyalásaira).

Az EUSZ lehetôvé tette a kétéves tárgyalási periódus meghosszabbításának lehetőségét, ugyanakkor nem tartalmazta a kilépési eljárás megszüntetésének, a szándéknyilatkozat visszavonásának kérdését. Az Európai Bíróság döntése a tagállami szuverenitás jegyében feljogosította az Egyesült Királyságot szándéknyilatkozatának egyoldalú viszszavonására.

A kilépési megállapodás az Európai Unió és kilépő közötti ügy, elfogadásához az Európai Tanácsban emelt küszöbủ minősített többség, az Európai Parlamentben egyszerú többség elégséges. Sajátos fejlemény a Bizottság dominánssá válása a „nehézsúlyú” Michel Barnier főtárgyalóként való kinevezésének köszönhetően.

A vonatkozó rendelkezések érdekes egyveleget eredményeztek az Egyesült Királyság az Európai Unió munkájában való részvételét illetően. Az 50. cikk a kilépő tagállamot

Halmai (szerk.) (2020) i. m. 69-82. 
megfosztja az uniós tanácskozási és döntéshozatali folyamatokban való részvételtől, amelyre ezáltal viszont a kilépés bekövetkeztéig jogosult. Az Egyesült Királyság így nem látta már el a soros elnökségi feladatokat, és biztosa lemondását követően nem volt hajlandó új jelöltet megnevezni sem. A brit állampolgárságú uniós tisztviselők továbbfoglalkoztatása tekintetében az EU személyzeti szabályzata az irányadó. Az Egyesült Királyságban múködő uniós intézményeket értelemszerủen áttelepítették (például Gyógyszeripari Ügynökség Párizs székhellyel).

Végül, de nem utolsósorban a kilépés és a jövőbeni kapcsolatok feltételei kizárólag két külön megállapodás keretében rendezhetők, az első elfogadása egyszerűsített döntéshozatali rend keretében történik, utóbbi a nemzetközi szerződések megkötésére vonatkozó uniós jogi rendelkezések szerint, ezek jelentős részét a tagállamoknak alkotmányos berendezkedésük szerint ratifikálniuk kell.

Halmai Péter: A brexit gazdaságtana címú átfogó tanulmánya ${ }^{8}$ az Egyesült Királyság kilépésével együtt járó közgazdasági összefüggéseket foglalja össze.

Gazdasági tekintetben a brit döntéshozók megfontolása az volt, hogy a) bizonyos mértékig hozzáférjenek az EU egységes termék- és szolgáltatáspiacához, b) mentesüljenek az uniós jogszabályok - így a munkaerő szabad áramlására vonatkozó előírások - alkalmazásának kötelezettsége alól és egyúttal c) kikerüljenek az Európai Bíróság joghatósága alól, illetve d) megszabaduljanak az uniós költségvetésbe történő befizetési kötelezettségüktől is. Az Unió elhagyására vonatkozó döntés jelentős következményekkel jár a kereskedelemre, a beruházásokra, a termelékenységre, a jövedelmekre, a munkapiacra és a közpénzügyekre. E hatásokat a tanulmány a lehetséges gazdasági forgatókönyvek szerint és öt kulcsdimenzió köré szerveződve vizsgálja, amelyek:

- külkereskedelem az EU-val és más gazdaságokkal;

- külföldi közvetlen tőkeberuházás;

- munkaerő és bevándorlás;

- a kereskedelem, a migráció és a gazdasági szabályozás hatása a termelékenységre;

- az EU-tagságból és egyéb konstrukciókból származó fiskális költségek.

Uniós tagként az Egyesült Királyság hozzáféréssel rendelkezett az - EU-tagállamok és EGT-országok alkotta - egységes piachoz, ugyanakkor e piac múködésétől elválaszthatatlan az áruk, szolgáltatások, személyek és tőke szabad áramlása, amely értelemszerúen a kapcsolódó sztenderdek harmonizálását vonja maga után. A tagság továbbá preferenciális piacra jutást tett lehetővé számára az országokban (és viszont), amelyekkel az EU kereskedelmi megállapodást kötött. A tagság az Egyesült Királyság gazdasága számára kiemelkedő fontosságú pénzügyi szektor számára lehetőséget nyújt arra, hogy - az úgynevezett passporting alapján - szolgáltatást nyújthasson a belső piac egészén. Az EU-tagság pozitív hatása egyértelműen kimutatható az Egyesült Királyság prosperitásának, gazdasági kibocsátásának és termelékenységének növekedésében, és javította gazdasági érdekérvényesítő képességét is.

Külkereskedelem az EU-val és más gazdaságokkal: az EU az Egyesült Királyság legnagyobb kereskedelmi partnere, az EU-tagság csökkentette a kereskedelem költségeit - a vámjellegű akadályok megszüntetésével és a nem-vámjellegű akadályok (például

E tanulmány szerkesztője Pásztor Szabolcs. Halmai (szerk.) (2020) i. m. 83-208.

Európai Tükör 2021/1. 
származási szabályok ellenőrzése) folyamatos kiiktatásával. Ennek köszönhetően az Egyesült Királyságban jelentősen növekedett a külkereskedelmi forgalom volumene, ösztönözte a specializációt, foglalkoztatást, áttételes hatásként érvényesült továbbá a termelékenység, kibocsátás, a jövedelem és életszínvonal emelkedése, erősen javult továbbá az export hozzáadottérték-tartalma és az ország a globális értékláncokba történő beágyazottsága. A legelőnyösebb hozadékkal az iparágon belüli kereskedelem rendelkezik, az intenzívebb verseny kedvezően hat az innovációra, technológiai fejlődésre és nyereségességre.

Külföldi közvetlen tőkeberuházás: az Egyesült Királyság a külföldi tőkebefektetés hagyományos, globálisan is kiemelkedő jelentőségű célpontja, az ország gazdasági teljesítmények fontos tényezője; pozíciója megszerzését mind keresleti, mind kínálati oldalon rendkívül kedvező adottságainak köszönheti. Az uniós tagság attribútumai, kiemelten az áruk, szolgáltatások és személyek a belső piacon való szabad áramlása növelte az Egyesült Királyság külföldi tőkevonzó képességét. A beruházások nagy része az Európai Unióból - és az Egyesült Államokból - érkezett, és a komparatív előnyökkel rendelkező gazdasági szektorokba összpontosult. Az európai integráció a külföldi közvetlen tőkeberuházásra gyakorolt szignifikáns hatását a kutatások kimutatják - igaz 2009 után a belső piac e hatása már mérséklődött.

Munkaerő és bevándorlás: az Egyesült Királyság bevándorlás szempontjából is hagyományos célországnak minősül, mindenesetre munkaerőpiacának megnyitása a kelet-közép-európai tagállamok munkavállalói előtt a beáramlás nagymértékű emelkedését váltotta ki, amely folyamat mára stabilizálódott. A nagyságrendi hatáson (a brit munkaerő 6\%-át uniós tagállamból érkezett munkavállalók alkotják) túl, ki kell emelni a migránsok magas foglalkoztatottsági rátáját, pozitív hatásukat a termelékenységhez, gazdasági kibocsátáshoz, közpénzügyekhez, miközben jelenlétük állítólagos munkabér-leszorító hatását az elemzések nem tudták kimutatni. Jellemzően fiatal életkoruk kedvező demográfiai szempontból is.

A kereskedelem, a migráció és a gazdasági szabályozás hatása a termelékenységre: az Egyesült Királyságot sem uniós tagsága, sem hagyományai nem korlátozták a dereguláció terén. A mérsékelten szabályozott termék- és munkaerőpiaci országok közé tartozik. Figyelemre méltó, hogy a leggyengébb teljesítményt a hazai hatáskörbe eső (például építésügyi) szabályozás terén nyújtja. A tanulmány valószínűsíti, hogy a kilépést követően a megszűnő hatályú uniós szabályozást - az egységes piacra jutás érdekében - hasonló hazai előírásokkal helyettesíti.

Az EU-tagságból és egyéb konstrukciókból származó fiskális költségek: az Egyesült Királyság uniós költségvetéshez való hozzájárulása gazdaságának méretével összevetve mérsékeltnek minősíthető, különösen az 1984-ben kiharcolt visszatérítést figyelembe véve. Ugyanakkor le kell szögezni, hogy a KAP-támogatások korlátozott haszonélvezője, a kohéziós politikai források pedig elsődlegesen a kevésbé fejlett régióiba (kiemelten Észak-Írország, Skócia) áramlanak. Az Egyesült Királyság az uniós költségvetés egyik legjelentősebb nettó befizetője volt.

A lehetséges forgatókönyvek tekintetében a reálgazdasági dezintegráció legmagasabb fokát a teljes szakítással járó, megállapodás nélküli, úgynevezett. kemény (hard) brexit jelenti. Mindenekelőtt, az Egyesült Királyság kilépésével kikerül az EU-vámunió keretéből, önállóan a WTO rendszerébe kerül át. Az Egyesült Királyság és az Európai 
Unió között vámhatár jön létre, egymással szemben a WTO-megállapodások alapján határoznak meg és érvényesítenek vámot. Hangsúlyozni kell, hogy a kereskedelmet nemcsak az így kivetett vámok, hanem az adminisztráció, nem vámjellegú akadályok is terhelik további költségekkel. Ebben a felállásban az Egyesült Királyság összes egyéb politikai ambíciója is teljesül: képes lezárni a munkaerőpiacát, területén nem hatályosak az uniós jogszabályok.

A vámunió megőrizhetné a piaci hozzáférést - a pénzügyi szolgáltatások és mezőgazdasági termékek kivételével. A vámunió tagjai egységes vámtarifát alkalmaznak a nem tag országokkal szemben. A vámuniós tagság nem mindig esik egybe az EU-tagsággal (lásd Andorra, San Marino, Törökország stb.). További előnye, hogy nem jár együtt az uniós költségvetésbe való befizetéssel, és a közösségi vívmányok alkalmazása is csak a kereskedelmi szabályozás terén kötelező. Ugyanakkor utóbbi megalkotásába a vámuniós partnernek nincs beleszólása.

Az Európai Szabadkereskedelmi Társulás tag Svájc és az Európai Unió közötti együttműködés is felmerült lehetséges forgatókönyvként: a belső piacra kétoldalú megállapodások útján és a belső piaci szabályok alkalmazásával fér hozzá. Ez a felállás nem oldja meg a bankok passporting problémáját, illetve fennmarad az uniós költségvetéshez való hozzájárulás követelménye is.

$\mathrm{Az}$ Európai Gazdasági Térséghez hasonló státusz a belső piachoz való hozzáférés megőrzését jelentené, ugyanakkor nem adna választ a brexit legfontosabb kiváltó okaira, a nemzeti szuverenitás visszavételére a jogszabályalkotás terén, a munkaerőpiac kontrolljára. Norvégia helyzete jól illusztrálja a kötöttségeket. Biztosítania kell az egységes piac múködésével összefüggő teljes joganyagnak való megfelelést, a négy alapszabadság érvényesülését, továbbá pénzügyileg hozzájárul a kohéziós politikai kiadásokhoz is - a kedvezményezett tagállamoknak nyújtott támogatás útján. Nem tagja azonban a vámuniónak.

A tanulmány kiemelkedően fontos része a brexit gazdasági hatáselemzése. ${ }^{9}$ Bemutatja az elemzések módszertanát, lehetőségeit, dimenzióit. A hatásvizsgálat kiindulópontja, a dezintegráció a kereskedelmi költségek növekedését okozza. Annak hatására csökken a külkereskedelem, a gazdaság nyitottsága. Mindez a termelékenység és a kibocsátás, a GDP-integráció révén elérhetőnél alacsonyabb szintjéhez, azaz nettó veszteséghez vezet. A teljes dezintegrációs veszteséget a közvetlen statikus hatásokon túl a dinamikus hatásokat is tartalmazó elemzések képesek kimutatni. A külföldi működő tőke beáramlásának jövőben dinamikája is jelentős mértékben a kereskedelmi költségek növekedésétől függ. Az inputok importjának és a kibocsátás exportjának növekvő költségei, az FDI-állomány jelenlegi összetétele mellett negatív hatást valószínűsítenek. A multinacionális tevékenységre gyakorolt hatás (mint azt az autóipari elemzések jól mutatják) jelentkezik a gyártó helyszín reorganizációjában. A migráció korlátozásai előzetesen nehezen becsülhetők, ám a GDP csökkenése tetten érhető következmény. Az Egyesült Királyság számára jelentős kihívás az egységes piac elhagyása. Az új piacok

A szerző több művében behatóan vizsgálta a Brexit problémakörét. Lásd: Halmai Péter: A Brexit lehetséges gazdasági hatásai. Európai Tükör, 21 (2018), 2. 7-32.; Halmai Péter: A dezintegráció gazdaságtana. A brexit esete. Közgazdasági Szemle, 67. (2020), 9. 837-877.; Halmai Péter: A populizmus ára: a Brexit adó. Magyar Tudomány, 181. (2020), 12. 1621-1635., Halmai Péter: Mélyintegráció. A Gazdasági és Monetáris Unió ökonómiája. Budapest, Akadémiai Kiadó, 2020.

Európai Tükör 2021/1. 
kiépítése időigényes folyamat. A távoli piacok pedig számos ágazatban nem jelenthetnek alternatívát a természetes partnerként kínálkozó európai piacokkal szemben. E kedvezőtlen fejlemények a termelékenység csökkenését eredményezhetik. A legtöbb formalizált megközelítés hosszú távon is nettó veszteséget prognosztizál a kibocsátás és jövedelmek terén is.

Mint kitűnik, a) a puhabrexit-forgatókönyv nem enged nagyobb változást a szabályozórendszerben, b) bármely forgatókönyv kedvezőtlenebb feltételeket eredményez, mint az Egyesült Királyság EU-tagként élvezett előnyei, c) a brexit előnyei gazdasági tekintetben nem alátámaszthatók.

Elekes Andrea Nemzetközi kereskedelem - mi várható a pénzügyi szolgáltatások területén? című műve ${ }^{10}$ olyan kritikus kérdéseket rendez keretbe, amelyekre az Európai Unióval megkötött Kereskedelmi és Együttmúködési Megállapodás sem adott választ. Az Egyesült Királyság pénzügyi szektora az unión belüli pénzügyi szolgáltatási piac egyik legnagyobb szereplője, széles tevékenységi körrel, számos nagyvállalat, nemzetközi bank európai központjával. Egyrészt azonban egyidejúleg kell megküzdenie három folyamat, a brexit, a pénzügyi válság és a digitalizáció generálta szabályozói és intézményi változások következményeivel, amelyek idő-, költség- és erőforrásigénye kiemelkedő nagyságrendű. A másik oldalon a szektor erősségei között szerepel a képzett munkaerő és a „passporting” intézménye, azaz a pénzügyi termékek és szolgáltatások szabadon értékesíthetők az Európai Unió területén. A szerző emlékeztet a tényre, miszerint a pénzügyi válság, a megnövekedett kockázatok és az új szabályozóknak való megfelelés kihívásai a dinamikát kedvezőtlenül befolyásolták, visszaszorulást előidézve a pénzügyi intézményrendszerben, a pénzügyi szolgáltatói, kiemelten külföldi tevékenységek körében és ezek volumenében. A brit pénzügyi szektor számára kulcsfontosságú aktivitásának fenntartása az EU területén történő termék- és szolgáltatásnyújtás (kiemelten hitelezés, betétgyűjtés, beruházási banki szolgáltatások, kockázatok menedzselésére és fedezetére alkalmazott származékos termékek értékesítése) terén.

A tanulmány számba veszi, hogy milyen változást hoznak a kilépést követő lehetséges alternatívák a pénzügyi szolgáltatások tekintetében. Megállapítható, hogy a legkedvezőbb megoldást - mint más ágazatok esetében is - az EGT-tagság jelentené, ez garantálja a megszerzett passport engedélyek alkalmazását és a szabad munkaerő-áramlást, azonban utóbbi és az uniós szabályoknak való megfelelés okán politikailag felvállalhatatlan. A passporting és a kölcsönös elismerés rendszerének biztosításával együtt járó szabadkereskedelmi megállapodás esetében a nyújtható szolgáltatások köre alapvetően megőrizhető lenne. Értelemszerűen a megállapodás nélküli alternatívák jellegüktől függően romló feltételeket támasztanának.

London mint pénzügyi központ versenyképességét a brexit kritikusan érinti az üzleti környezet, ${ }^{11}$ emberi erőforrás ${ }^{12}$ és infrastruktúra ${ }^{13}$ tekintetében. A szerző figyelmeztet az új rendszerek bevezetésének komplexitására, a kidolgozás és tesztelés folyamata jelentős erőforrást vonhat el az üzleti fejlesztéstől és innovációtól.

Halmai (szerk.) (2020) i. m. 209-226.

11 Az EU-ügyfélkör elvesztése, méretgazdaságossági előnyök kihasználatlansága, új, kedvezőtlenebb szabályok, relokációs döntések, a jogi megfelelés és szerkezetátalakítás költségei.

12 A szabad munkaerő-áramlás megszűnése, amelyet a kvótarendszer valamelyest kompenzál.

13 Esetleges piacvesztés, tevékenységek relokációja, technológiai fejlesztési problémák. 
Izgalmas felvetéssel foglalkozik Kutasi Gábor A brexit árfolyamhatása a nagy-britanniai magyar munkavállalók szemszögéből címú tanulmánya. ${ }^{14}$ Arra keresi a választ, hogy a font a brexit bizonytalanságból adódó árfolyamvesztése és az ezzel egyidejüleg jelentkező hazai szakképzett munkaerőhiány hogyan érinti az Egyesült Királyságban dolgozó magyar állampolgárságú munkavállalók maradási szándékait. A vándorlás logikája - a gazdasági racionalitás és haszonmaximalizálás alapján -, hogy a várható haszonnak meg kell haladnia a vele járó költségeket. Következésképpen meghatározó tényező a bérkülönbség (egyenes arányban), a hazai munkanélküliség és foglalkoztatási lehetőségek, a földrajzi távolság (fordított arányban) és a kulturális (nyelvi) távolság. A vándorlást segítheti, ösztönözheti továbbá a meglévő kapcsolati háló, a legális munkavállalás lehetősége vagy hazai sokkhatás (például háború, munkanélküliség). A szerző hangsúlyozza, hogy a kezdeti erős kivándorlási dinamikát idővel egyensúlyi helyzet, majd visszaáramlás megindulása váltja fel. Emellett felhívja a figyelmet az egyéni megfontolások súlyára, azaz a kivándorlás a körülmények fennállása esetén sem automatikus folyamat.

A migráció gazdasági hatásai között ki kell emelni a migrációs többletet. Az új munkaerő alacsonyabb bérelvárással, alacsonyabb hozzáadott értékű ágazatokba áramlott, amely csökkentette ugyan a brit gazdaságban az átlagbért, de összességében több munkahelyet és kibocsátást eredményezett. E haszon kiegészült a helyben elköltött jövedelmükkel is. Az Egyesült Királyság számára a bevándorlásnak pozitív hatása volt a GDP növekedésére, a termelékenységre és az államháztartásra, sőt a demográfiai folyamatokra is. A kibocsátó ország számára a vándorlás a jövedelmi hatások, illetve a belső munkaerőpiaci problémák enyhítésén túl kedvező befolyással rendelkezett a többletjövedelem multiplikáló hatása révén. A hazautalt jövedelem hozzájárulhatott a hazai termelékenység javításához, a kibocsátás növeléséhez.

Az empirikus elemzés a font jelentős leértékelődését igazolta a brexit és az ezzel együtt járó politikai-gazdasági bizonytalanság következtében. A magyar munkavállalók esetében kimutatta a korrelációt a létszámuk és a font-forint árfolyam, továbbá a létszám és a forintban számított brit átlagbér között, ám a kontrollcsoportnak használt lengyel munkavállalók esetében csak utóbbi esetben sikerült az együtt mozgást alátámasztani. Ugyanakkor a szerző levonja a következtetést, nem várható a magyar munkavállalók tömeges visszatérése. Ettől a számos további fejlett EU-tagállam kínálta lehetőségek eltérítik a munkavállalókat.

Szarvas Erik A brexit Kereskedelmi Világszervezetet érintő összefüggései munkája ${ }^{15}$ annak feltárására összpontosít, hogy milyen következményekkel jár az Egyesült Királyság az egységes piacból, vámunióból és az EU közös kereskedelempolitikájából való kilépése. A szerző összefoglalja a döntésből adódó elsődleges teendőket. Ezek közé tartozik az önálló kereskedelempolitika kialakítása, a kereskedelmi védelmi intézkedésrendszer, illetve a két- és többoldalú megállapodásokon alapuló kereskedelmi kapcsolatrendszer létrehozása.

Az új brit kereskedelempolitika mozgásterét nagymértékben befolyásolja az átmeneti időszak tekintetében kötött megállapodás - amennyiben az uniós tagként élvezett előnyök fennállása és az uniós joganyag alkalmazásának követelménye az új rendszerre

\footnotetext{
$14 \quad$ Halmai (szerk.) (2020) i. m. 227-242.

15 Halmai (szerk.) (2020) i. m. 243-272.
} 
való átállást késlelteti, illetve az Európai Unióval való jövőbeni kereskedelmi együttműködés rendje.

$\mathrm{Az}$ építkezés meghatározó fontosságú eleme a Kereskedelmi Világszervezettel (WTO) való viszony újrarendezése; a szakértőket megosztotta, és számos értelmezés született az Egyesült Királyság a kilépést követő WTO-státuszáról, jogairól és kötelezettségeiről, kiemelten új piacnyitási kötelezettségvállalásai megtételének módjáról. A szerző felsorakoztatja az Egyesült Királyság önálló jogon való WTO-tagságának tényezőit, megerôsítve, hogy újracsatlakozás nem szükséges, ugyanakkor rámutat, hogy az uniót elhagyva saját piacra jutási kötelezettségeit rögzítenie kell, ehhez engedményes listáit meg kell határoznia és a WTO-tagokkal egyeztetnie. Az Egyesült Királyság kereskedelempolitikai célja az új berendezkedésre való áttérés és a kereskedelmi forgalom zökkenőmentes biztosítása volt, így törekedett az EU-vállalások reprodukálására.

Szemlér Tamás A brexit lehetséges hatásai az Európai Unió költségvetésére címú tanulmánya ${ }^{16}$ azokat a következményeket elemzi, amelyeket az Egyesült Királyság mint az uniós költségvetés egyik legjelentősebb befizetőjének távozása válthat ki. A szerző kiemeli, hogy a többéves pénzügyi kerettel összefüggő tárgyalássorozat nehézségei nemcsak a költségvetés nagyságrendjéből - azaz a nettó befizetők hozzájárulásának, illetve a nettó haszonélvezők számára allokált támogatás mértékéből -, hanem az erôteljes külső kihívások okozta nyomásából, a döntésekkel összefüggő elvi és értékválasztási konfliktusokból adódik. Az elmúlt évtizedekben érzékelhetővé vált politikai viták középpontjában a tagállami pozíciók, a nagyságrend és így a szolidaritás, illetve a tagállami be- és kifizetések viszonylagos egyensúlya áll, a diskurzusban háttérbe szorulnak a költségvetés másik három feladata és a kiadási oldal tartalmi kérdései. Az első csatlakozási kör időszakában a közös költségvetés kiadásainak meghatározó részét a Közös Agrárpolitika kiadásai tették ki, amelyből az Egyesült Királyság meglehetősen korlátozott mértékben részesült. Az ország relatíve magas befizetési szintjével együttesen ez kiugróan magas egyensúlytalanságot eredményezett, ennek jelentős csökkentését sikerült Thatcher miniszterelnök asszonynak elérnie az 1984-es fontainebleau-i csúcson elfogadott „brit visszatérítés” révén. Az egyik oldalon azonban sem az Egyesült Királyság regnáló kormányait, sem - mint a népszavazás is tükrözte - közvéleményét nem győzte meg ez a mechanizmus. Ugyanakkor növekvő feszültséget keltett e visszatérítést ténylegesen finanszírozó tagállamok között, igaz ők is többféle kedvezményt harcoltak ki maguknak.

A szerző összegzi a kilépés rövid távú, közvetlen következményeit, az Egyesült Királyság költségvetési hozzájárulásának megszűnését. A közvetett hatások között felhívja a figyelmet a brexit a tagállamok és régiók fejlettségi szintje tekintetében gyakorolt statisztikai vonzatára, amely a kohéziós támogatások jogosultsági feltételeinek módosulását, kiemelten a felzárkózó régiók potenciális forrásvesztésére - amennyiben egy főre jutó gazdasági kibocsátásuk „átbillen” az uniós átlag 75\%-os határán.

A gazdasági növekedés lassulása kedvezőtlenül érinti a költségvetés bevételeit, utóbbi folyamat elvezethet a GNI-alapú bevételek megnövekedett súlyához és az ebből adódó politikai feszültségekhez. Nyitott kérdés az is, hogy az Egyesült Királyság kimaradása hogyan változtatja meg a költségvetési tárgyalások erőviszonyait és dinamikáját. A tágabb horizontot illetően, a brexit fejleménye hozzájárulhat - valószínúleg az európai integráció

$16 \quad$ Halmai (szerk.) (2020) i. m. 273-286.

Európai Tükör 2021/1. 
jövőjének továbbgondolásával együttesen - a hosszú ideje elmaradt költségvetési reform realizálásához. A szerző emlékeztet az új szemlélet szükségességére, ennek részként a korszerű uniós szakpolitikák középpontba helyezésére, a forrásukat biztosító közös és autonóm bevételek konzisztens, átlátható rendszerének megteremtésére, ugyanakkor zárásként azt is leszögezi, hogy a brexit önmagában nem fogja a költségvetési reformokat kiváltani.

Kutasi Gábor és Regős Gábor A brexit exportra gyakorolt hatása brit és magyar szemszögböl címü tanulmánya ${ }^{17}$ felvezetése, miszerint az egységes piacból való kilépés után nem lesz érvényes a fizikai, fiskális és technikai korlátok nélküli kereskedelem, mára nagyjából már realizálódott. A kereskedelmi dezintegráció folyamatának megértéséhez a világkereskedelmi versenyképesség és az integráció-gazdaságtan elméleti megközelítéseit hívják segítségül, módszertan tekintetében kiegészítve a kiszámítható általános egyensúlyi (CGE-) modellel és az erre épülő gravitációs modellel. A szerzők célja a brexit a brit és a magyar gazdaságra gyakorolt kereskedelmi hatásának számszerúsítése a kilépést követő forgatókönyvek alapján. 2006 után az EU súlya a brit külkereskedelmi mérlegben csökkenő irányzatot mutatott.

A kiszámítható általános egyensúly modellel végzett becslések irányukban megegyező, ám nagyságrendjükben különböző becsléseket adtak, közös elemük azonban, hogy mind optimista (szabadkereskedelmi megállapodás, illetve a norvég/svájci EGT-jellegû) és pesszimista szcenárió (WTO) esetén is mindenképp a volumen csökkenése valószínűsíthető. Kiemelik, hogy a hivatkozott országos, illetve regionális (Skócia) szintű elemzések egy része nagyon jelentős, körülbelül 25\%-os kereskedelemcsökkenést vetített előre a WTO-forgatókönyv esetében.

A brexit magyar kivitelre gyakorolt hatását illetően a tanulmány emlékeztet a termékexport hullámzó jellegére. Bár az Egyesült Királyság 2016-ban a 9. legfontosabb célország volt a magyar exporttermékek számára, a 2008 és 2016 között időszakban összességében csökkent a brit piac szerepe a teljes magyar termékexporton belül. A szolgáltatások terén ugyanebben az időszakban szinte minden évben növekedést mutatott az export értéke, és a brit piac a 3. legfontosabb célország volt Magyarország számára 2016-ban. A gravitációs modell a „hard brexit” esetében mind a termékek, mind a szolgáltatások exportjának szignifikáns visszaesését prognosztizálta, ám a szerzők óvatosságra intenek: míg a hatás irányát az együtthatók egyértelmúen meghatározzák, a nagyságrendjét eltúlozzák. A „soft brexit” esetében a termékkivitel és a teljes export mutatószámai nem különböznek lényegesen a „hard brexit” előrejelzéseitől, ám a szolgáltatások exportjának volumene kapcsán még növekedés is prognosztizálható. A tanulmány azonban aláhúzza, hogy mivel az EFTA-tagországok száma alacsony, ezért ezen országok országspecifikus jellemzői torzíthatják az eredményeket.

A tanulmánykötet írásai mozaikszerúen rajzolják ki a brexit népszavazás és valószínűsíthető következményeinek összetett kontextusát, az összképben azonban jól tetten érhetők a narratívák és elemzések közös szálai. A brexit népszavazáshoz vezető út gyakorlatilag az Egyesült Királyság csatlakozásának időpontjáig vezethető vissza. Az ország különálláson alapuló identitása nemcsak az együttmúködésre nyomta rá bélyegét, hanem előrevetítette az esetleges távozás felvállalását is. A döntési szükséglet előtérbe kerülését egyaránt segítették az Európai Unió megszületéséhez és működéséhez

Halmai (szerk.) (2020) i. m. 287-302.

Európai Tükör 2021/1. 
kapcsolódó, az elmúlt évtizedekben érzékelhetően erősödő ellenmítoszok és a brit pártrendszer sajátos pártdinamikai jelenségei. A stratégiai kérdések tekintetében homogenizálódó platformot képező két váltópárthoz képest a UKIP tényleges választási alternatívát képviselt: a nemzeti szuverenitás vélt visszaszerzését - az uniós jogi kötelmektől, így a négy szabadság elvétől való „megszabadulás”, a brit munkaerőpiac lezárásának lehetőségét -, valamint az uniós költségvetési befizetési kötelezettség megszűnését kínálta. A népszavazás eredménye mind a brit politikai elitet, mind az Európai Uniót váratlanul érte. A kilépési szándéknyilatkozat elhúzódó megküldése jól illusztrálta a kormánypárt megosztottságát, a kiérlelt koncepciók teljes hiányát; az Európai Unió részéről részletes eljárásrend nélkül a precedenst kellett megteremteni, mégpedig olyan jellegút, amely a további kilépést fontolgatókat kellőképpen elbátortalanítja.

A kilépésre vonatkozó döntés egyértelműen politikai indíttatású volt, gazdasági alapon a választás előnyei nem támaszthatók alá. A kilépési folyamat első fázisának részeként aláírt kilépési megállapodás garantálta az egymás területén élő brit, illetve uniós állampolgárok megszerzett jogait, az északír-ír „soft” határ megtartását és az Egyesült Királyság által vállalt pénzügyi kötelezettségek teljesítését. A kézirat lezárásának időpontjában számos alternatíva nyitva állt az Egyesült Királyság és az Európai Unió, a második fázisban meghatározott jövőbeni együttműködése tekintetében, egyik opció sem eredményezhetett azonban az uniós tagságnál kedvezőbb helyzetet. A vámunióból való kilépés - mint a későbbi megállapodás tartalmazta - még az egymással szembeni vámérvényesítés hiányában is megnöveli a nem vámjellegủ terheket. A várható hatásokat elemző modellek a kereskedelmi hatások tekintetében azzal a feltételezéssel éltek, hogy az Egyesült Királyság nem lesz képes időben felkészülni az egységes piac veszteségeinek pótlására új kereskedelmi egyezményrendszer kialakításával. A szerzők figyelmeztetnek a pénzügyi szolgáltatások piacvesztésének veszélyeire, illetve a külföldi működőtőke-beáramlás dinamikájának és a megváltozó kereskedelmi költségek összefüggéseire. A munkaerőpiac korlátozása felülírja a bevándorló munkavállalók a termelékenységre, kibocsátásra, belső fogyasztásra, sőt demográfiai folyamatokra gyakorolt kedvező hatását is. Félő, hogy a multinacionális gazdasági szervezetek kiáramlása is. Összességében, a legtöbb formalizált elemzési modell nettó veszteséggel számol mind a kibocsátás, mind a jövedelmek terén. A tényleges problémák megjelenése nem váratott sokáig, január első napjaitól sokasodnak az új berendezkedés gazdasági nehézségei. Előbb-utóbb politikai dimenziót nyernek.

A kötet szükségképpen nem tartalmazhatja a kézirat lezárása utáni fejleményeket. A bemutatott, a legkorszerúbb nemzetközi szakirodalmat is feldolgozó elméleti háttér azonban mélyebben megvilágítja és kontextusba helyezi a folyamatokat. Ilyen módon kulcsot nyújthat az eddigi és sok tekintetben a jövőbeni folyamatok megértéséhez is. 